\title{
The Changing Structure of the Academic Job Market*
}

\section{A. Lanethea Mathews, Syracuse University}

$\mathrm{N}$ umerous recent articles (e.g., Hartle and Galloway 1996; Lapidus 1997; Pfannestial 1998; Wilson 1996) examine the "crisis" state of the current academic job market. Conventional labor market indicators, however, often suggest more favorable conditions for new doctorates than one would expect given growing feelings of pessimism within the halls of higher education (Barkume 1996-97). Although many professional associations and university administrations keep records of their graduates' placement success, statistics on the academic job market are not coordinated, easily available, or consistent across disciplines. ${ }^{1}$ In this article, I first consider whether perceived changes in academic employment can be documented empirically. Second, I suggest that it is important to share information about the current structure of the job market and the composition of faculty in higher education with current doctoral students seeking a realistic picture of career opportunities. Third, I conclude by suggesting that more empirical data about the job market must be collected before an accurate model of how changes in the marketplace affect doctoral education and employment can be constructed.

\section{Recent Trends}

According to the Association of American Universities (AAU), "unemployment among new doctorates has consistently been low," and Ph.D.s continue to maintain high levels of employment throughout their careers (AAU 1998). Only 2\% of 1991-95 AAU university doctoral graduates ${ }^{2}$ were unemployed in 1995. The unemployment rate for

A. Lanethea Mathews is a doctoral candidate in political science at Syracuse University. Her research interests include women's electoral politics, gender, and the relationship between civic life and political power. political and related sciences was approximately $1 \%$ in $1995 .^{3}$ Looking only at unemployment rates, the academic job market appears to be doing better than most other markets (although doctorates in some disciplines, like mathematics, which had a $14.7 \%$ unemployment rate in 1997, are much worse off [Magner 1997)).

What these numbers do not reveal, however, are answers to important questions about the nature of employment for Ph.D.s and the type of work they are doing, about the composition of higher education faculty, and about the likelihood of continuous employment in one job versus a series of jobs. Unemployment rates do not say much about how Ph.D.s' employment draws meaningfully on their doctoral training, or if it fails to do so (AAU 1998). Finally, while most Ph.D.s eventually find work doing something, nearly $40 \%$ of the class of 1995 were still seeking employment or postdoctoral placement at the time of graduation-a figure that suggests Ph.D.s are not having an easy time landing the jobs they want, at least not quickly (AAU 1998).

\section{Full-Time Tenure-Track Jobs}

During the $1960 \mathrm{~s}$, the percentage of faculty in full-time tenure-track jobs hovered between 50 and 55\% of all individuals holding faculty positions. By 1980, this figure had climbed to approximately 63 to $68 \%$. It held relatively firm until about 1988, when the situation began to reverse (Bowen and Schuster 1986). Although the absolute population of full-time faculty increased by $25 \%$ between 1975 and 1993, only about $50 \%$ of full-time faculty members were tenured by 1993 (National Center for Education Statistics [NCES] 1996). The proportion of full-time faculty not tenured but on the tenure track decreased from $29.1 \%$ to $20.8 \%$ during this same period. And in the largest change by far among full-time faculty, the proportion of individuals ineligible for tenure increased from $18.6 \%$ in 1975 to $27.3 \%$ in 1993 (National Education Association [NEA] 1997).

\section{Part-Time Jobs}

The increase in the number of full-time faculty members not on the tenure track has been accompanied by an increase in the number of part-time faculty (also usually not on the tenure track). ${ }^{4}$ Although there is nothing new about the presence of part-time faculty members at U.S. institutions of higher education, one estimate suggests that the number of part-timers grew by $48 \%$ (from 254,800 to 376,400 ) between 1987 and 1992 (Schuster 1998). ${ }^{5}$ The proportion of part-time faculty members among "senior instructional staff" at all institutions increased from $22 \%$ in 1970 to $34 \%$ percent in 1987 (Rhoades and Hendrickson 1997), and had reached more than $40 \%$ by 1993 (Conference on the Growing Use of Part-Time and Adjunct Faculty 1997). The American Association of University Professors recently found that the number of lecturers (nontenureable, usually part-time instructors) at universities more than doubled from 1987 to 1995 (Wilson 1996). Now, nearly one-half of all faculty at institutions of higher education occupy parttime positions (Benjamin 1998).

\section{Postgraduate Employment Commitments and Postdocs}

The decline in full-time and tenure-track jobs is mirrored in the

\section{ONLINE RESOURCE}

For more details on the Conference on the Growing Use of Part-Time and Ad junct Faculty and the work of the Coalition on the Academic Work Force, be sure to visit a special PSonline section at www.apsanet.org/PS/adjunct/. 
steadily decreasing number of graduates reporting postgraduation employment commitments. In the 1970s, almost three-quarters of doctoral students secured jobs prior to graduation. During the $1990 \mathrm{~s}$, the proportion never exceeded twothirds. In 1993 , only $52 \%$ of new Ph.D.s had definite employment commitments in higher education, down from $68 \%$ in 1970 (Hartle and Galloway 1996). By 1996, about onethird of all new doctorate recipients were still seeking employment or postdoctoral assignments at the time they received their degree. Among those degree recipients with postgraduation employment commitments, the proportion going into academia had decreased, while the proportion heading for industry or the private sector increased (National Research Council 1996). Seventyone percent of Ph.D.s with postgraduation commitments planned to teach and $29 \%$ planned postdoctoral study; only $18 \%$ planned postdoctoral study in 1976. Some Ph.D.s reported having taken as many as four postdoctoral appointments in succession, noting that they found it difficult to find full-time or tenure-track jobs (Barkume 1996-97).

These percentages do vary by field. In 1996, for example, Ph.D.s in education were most likely to have a commitment for either work or study; Ph.D.s in the humanities were least likely. In the social sciences, about $65 \%$ of doctorates with degrees in hand had definite commitments for work or postdoctoral study following graduation (National Research Council 1996).

\section{The Current Situation}

Today, a faculty member is more likely to be a woman and a member of a minority racial/ethnic group, and less likely to be U.S.-born and to hold a tenure-track position than at any time in the past (Magner 1996a).

Today's nontenure-track Ph.D.s are often temporary workers. In 1993, more than one-half $(50.8 \%)$ of all higher institution faculty members had one-year employment contracts and $15 \%$ had contracted for only one academic term. In addition, about one-third of faculty had contracts for a limited number of years
BULLETIN BOARD

\section{Actions Required to Improve Doctoral Education}

1. Spend more time, money, and effort on career planning and placement activities for doctoral students.

- Establish collaboration between career planning and placement centers and academic departments for career planning workshop activities to be offered starting the third year of the doctoral program.

- Work with faculty to broaden the acceptance of business-, government-, and/or nonprofit-sector careers as legitimate and desirable Ph.D. outcomes.

2. Continue to support all students to complete their degrees.

- Continue to reward research mentoring by faculty.

- Assist minority students to find mentoring and establish networks across departments.

3. Focus on postdoctoral appointees.

- The graduate dean or the vice chancellor for research must assume responsibility for postdoctoral affairs.

- A maximum of 5 or 6 years should be spent in a postdoctoral position.

- Postdocs should be ensured adequate training, salary, and health insurance.

- Postdocs should be ensured adequate professional development opportunities, including opportunities to pursue skills training and participate in workshops and conferences.

- Administrators should foster development of a postdoctoral community.

4. Improve assessment of program by students.

- Conduct surveys of students at regular intervals throughout their doctoral studies.

- Require students to complete an exit survey/interview.

- Conduct a five-years-out benchmark survey on program satisfaction (e.g., Would you still pursue a Ph.D. in your field? Would you still study at this university?)

5. Develop creative solutions for the problems faced by dual-career couples.

- Work to heighten awareness of dual-career concerns among all individuals in the hiring process.

- Be more willing to accommodate the needs of spouses when making hiring decisions.

- Support the establishment of a more family-friendly university, especially for women in science and engineering.

Editor's Note: These recommendations were adapted from Maresi Nerad and Joseph Cerny's "Career Paths of Ph.D. Recipients: Final Results from the 10 Years Later Study." The findings, which follow from a study of doctoral recipients in political science, biochemistry, electrical engineering, computer science, English, and mathematics, were first presented at a plenary during the 1999 annual meeting of the Council of Graduate Schools and first reported in the March 2000 issue of CGS Communicator. 
(NEA 1996). According to statistics compiled by NCES, in 1993, 50.6\% of all post-secondary appointments were classified as full-time permanent, $7.3 \%$ as full-time temporary, $19.6 \%$ as part-time permanent, and $22.5 \%$ as part-time temporary (22.2\% were additionally classified as adjunct). Part-time faculty members teach about $25 \%$ of all collegelevel courses, with the percentage being highest at the community college level (NEA 1995). Although many individuals teach part-time out of choice or in conjunction with other careers, a full $43 \%$ of parttimers said they do so because no full-time position was available (NEA 1995). Assuming that recent graduates want full-time, tenuretrack positions, this data suggests that most Ph.D.'s face a multipleyear job search in the late 1990s and early 2000 s.

Reported job satisfaction among the new generation of higher education faculty members reflects the uncertainty and frustration that accompanies recent changes in the academic job market. Although most people with nontenure-track faculty positions seem to be reasonably satisfied with their current jobs, the 1993 NCES National Study of Postsecondary Faculty indicates that a significant portion are not. Fortythree percent of nontenure-track faculty members indicated that they were dissatisfied with job security; $48.5 \%$ stated they were dissatisfied with time available to keep current in their field. Likewise, 53\% of respondents to the NCES survey reported being dissatisfied with opportunities for professional development in their career rank at the institution of their employment. Also on that survey, $53.5 \%$ of respondents working in nontenure-track positions indicated that it was likely that they would leave their current position for a full-time job at another postsecondary institution; $43.2 \%$ said they would leave to take positions outside of postsecondary education (reported in NEA 1996).

\section{Gender and Racial Disparities in the Academic Workplace}

Women have made substantial gains in academe, more than any other group. Between 1991 and 1995, women's representation among full-time and part-time faculty steadily increased, while, during that same period, men's representation in these positions held steady and even declined in the case of full-time positions (NCES 1998). The NCES reported that the proportion of women among those holding faculty positions increased from $27 \%$ to $39 \%$ between 1970 and 1993 (NCES 1996). ${ }^{6}$ Similarly, members of minority groups increased their representation on higher education faculties. Minorities held $2.2 \%$ of full-time positions in 1976 and 4.6\% in 1993 (although this proportion lags far behind that of enrolled minority students, particularly undergraduates). ${ }^{7}$ Only $43 \%$ of the current generation of faculty members are native-born white men, compared to $59 \%$ of the past generation-a sure indication that the composition of higher education faculty is changing, though not quite evenly across all types of institutions (Magner 1996a). Making up at least $41 \%$ of new faculty members, newly hired women outnumber newly hired men in liberal arts and community colleges, but comprise only one-third of new hires at doctoral institutions (Magner 1996a).

While both women and members of underrepresented racial/ethnic groups have made significant progress in obtaining positions in higher education, gender and racial disparities persist. The biggest increase for women faculty, for example, has been in nontenure (and nontenure-eligible) and part-time positions (NEA 1997). Men still hold the overwhelming majority of tenured positions ( $76 \%$, down from $82 \%$ in 1975). Eighty-three percent of all full professors in the social sciences are men, while only $16.7 \%$ are women. Women also trail significantly behind men in the ranks of associate professors-33\% compared to $67 \%$. By contrast, women are overrepresented in the category "in- structor/lecturer," holding $61.7 \%$ of those positions.

Women are also more likely to work part time than are men (NEA 1995). ${ }^{8}$ The NCES reports that almost half of women faculty $(49 \%)$ worked part time in 1993, compared to only $35 \%$ of men. Also, in that year, women made up $45.7 \%$ of full-time nontenuretrack faculty, but only $33 \%$ of full-time faculty (NEA 1996). Thus, although the majority of nontenure-track faculty members are men, women are overrepresented among holders of these positions. Similarly, although there is less of a disparity between members of minority racial/ethnic groups and whites than between men and women in terms of their likelihood to hold part-time positions, members of racial/ethnic minority groups are still overrepresented in nontenure-track positions.

\section{Political Scientists in the Academic Job Market}

Available statistics suggest that the experiences of political science Ph.D.s are similar to those of Ph.D.s in other disciplines. Most of the information on the experiences of doctorates in political science comes from annual placement surveys conducted by the American Political Science Association in conjunction with the Commission on Professionals in Science and Technology (CPST) and other professional associations with funds from the National Science Foundation. In 1998, APSA surveyed job seekers who received their degrees between July 1996 and June 1997. The survey collected information about doctorates' graduate training, professional development, job searches, employment statuses, job satisfaction levels, times in job search, and dual-career statuses. ${ }^{9}$

Like other sources of data on the academic job market, APSA's placement survey is limited in scope. Although some sort of placement survey has been distributed to academic 
department heads

since at least the

1970s, the category

"temporary posi-

tion" was not in-

cluded in the survey

instrument or in the

annual report until

1975; even then the

category encom-

passed all positions

not eligible for ten-

ure. Once the cate-

gory was included,

at least $30 \%$ of all

Ph.D.s placed in

academic positions

were classified as

temporary, a pro-

portion that re-

mained fairly stable

through 1979. The

appearance of "tem-

porary positions" on

political science

placement surveys is

itself a sign that the

demand for Ph.D.s

has changed over

the last two decades

(Roemer and Schnitz 1982).

APSA's 1996 placement survey indicates that $86 \%$ of the 417 respondents were employed at the time of the survey. About $71 \%$ of the respondents were employed in academic positions, though only $37 \%$ held tenure-track positions and only $48 \%$ had full-time positions. Of employed respondents, $46 \%$ of men and $53 \%$ of women were placed in full-time permanent positions, a finding somewhat reversed from gender disparities found across disciplines. Among U.S. citizens, $66 \%$ of women and $53 \%$ of men held fulltime permanent positions; $66 \%$ of women and $47 \%$ of men were on the tenure track. Although overall placement rates are high, indicators of job satisfaction are not too encouraging for future political scientists. Fifty-eight percent of respondents indicated they were satisfied with their career choice, but only $17 \%(\mathrm{n}=71)$ said they would recommend their career choice to others-a finding that may signal frustration with lack of career mobility or a perception of lack of employment opportunities.

Three hundred fifty-nine of the respondents were employed when they completed the survey. On average, they spent a year searching for their current jobs, and the range extended from 0 to 60 months. Eighty-two percent of the 359 were academically employed, with $43 \%$ employed in tenure-track positions and $38 \%$ in nontenure-track positions; $12 \%$ were employed in nonacademic positions. Including both nonacademic and academic jobs, $56 \%$ were employed full-time permanent, $2 \%$ parttime permanent, $26 \%$ full-time temporary, and $15 \%$ part-time temporary. Overall, $41 \%$ of respondents $(\mathrm{n}=141)$ believed they were underemployed in their current positions. In addition, $50 \%$ indicated that they were actively looking for another job (Mann 1998). Given these figures, it is unsurprising that $60 \%$ said they found their job search to be more difficult than they had expected.

\section{The Structure of the Job Market: What to Expect}

To summarize the most important findings above, recent Ph.D. graduates are no longer landing full-time tenure-track positions as frequently as members of previous academic generations did. As the population of higher education faculty has steadily increased, the growth in the numbers of faculty members ineligible for tenure and those working part-time, including those who hold multiple part-time jobs (the socalled "academic nomads," "wanderers," or "gypsies"), has also grown. Nontenure-eligible and part-time (often fixed-term) workers are increasingly the largest groups in the academic job market. Likewise, the number of Ph.D.s opting for postdoctoral work in the face of tight market competition is on the rise. New Ph.D. graduates can expect their search for full-time tenuretrack jobs to span multiple years.

Current academic labor market conditions, which encourage the hiring of part-time and nontenureeligible faculty, have the potential to constrain academic freedom, reduce educational opportunities, adversely affect undergraduate education, and erode tenure and professional autonomy (Benjamin 1998). Another concern is that continually employing temporary rather than permanent faculty may gradually shift authority away from faculty members to administrators (Foster and Foster 1998). Even more troubling, there is mounting evidence that such hiring patterns have divided faculty along caste lines (Conference on the Growing Use of Part-Time and Adjunct Faculty 1997), creating a twotier hierarchy in which one group conducts research and a second teaches (Reichard 1998). Whatever its effect, most students of higher education seem to agree that "the distinction between tenure- and nontenure-track appointments should be recognized as an essential category for analyzing the recent history of the academic labor market," and that, in some ways, this distinction has led to a dual labor market (Roemer and Schnitz 1982, 514).

The emergence of a dual labor market suggests that conditions favor discriminatory practices in academic employment (Roemer and Schnitz 1982). A potential and troubling result of all this is that the longer an individual works in parttime nontenure-track positions, or what the National Education Association refers to as "contingent" positions, the more difficult they will find it to land full-time tenure-track jobs. Although part-time and nontenure-track faculty are generally in the early years of their careers and, thus, need support and opportunities for professional development, they are generally disadvantaged, compared to their tenure-track colleagues, in terms of chances to secure research assistance, participate in professional association activities, take sabbaticals, and access other resources.

Typically, doctoral students are prepared for the academic job market by receiving instruction and guidance on teaching, presenting at conferences, publishing, and so on. 
This exclusive attention to what students must do after taking a job does not prepare them to deal with the realities of the job market they will face after they receive their degree. At the very least, preparing $\mathrm{Ph}$.D. students to succeed in the new academic job market will require advisors to inform students that landing a tenure-track position out of school might be an unrealistic expectation (Magner 1996b; Mann 1998).

Sheilah Mann's 1998 analysis of the APSA placement survey is a departure from past research on the academic job market. Mann noted that university and college departments need to give more attention to the difficulties graduates encounter as they seek employment. Among other things, Mann suggested that students should be trained for nonacademic careers, which she acknowledged would require changing the professional culture of graduate programs in ways that support students pursuing such careers. In addition, given the results of the APSA survey, graduates need not only more help publishing and presenting at conferences, but also collecting information about employment and career options, preparing for interviews, and building professional networks with schools and professional associations. Taking an important first step in this direction, APSA launched new careers and professional opportunities web pages in 1999 (www.apsanet.org).

There is some indication that professional associations and doctoral departments are beginning to recognize the realities of the job market. Association representatives to the 1997 Conference on the Growing Use of Part-Time and Adjunct Faculty, for example, concluded that "graduate programs can no longer prepare doctoral students exclusively for careers in research universities and continue to convey the message that success comes only in being a tenured professor." Indeed, many of the disciplines that have seen a slight improvement in placement rates of their Ph.D.s have done so because their graduates are increasingly taking jobs in business and industry (Magner 1997).

More research is needed about the nature of employment in higher education and the experiences of Ph.D.s who reach tenure-track positions after holding a succession of multiple part-time, nontenure-track jobs. The academic community knows surprisingly little about the sorts of jobs new Ph.D.s can reasonably expect to get after graduation, or the multiple steps many must take before securing a tenure-track position. Concerted effort should be made by professional associations and colleges and universities to compile data over time on this unexamined situation in higher education employment.

\section{Notes}

\footnotetext{
* The research presented here was supported by the Graduate School at Syracuse University through its participation in the Preparing Future Faculty program, sponsored by the Council of Graduate Schools and the Association of American Colleges and Universities, and made possible with funding from participating institutions and a grant from The Pew Charitable Trusts.

1. In consequence, data used in this paper are drawn from a multitude of sources spanning several years. I have tried to take care when making comparisons and cross-references across data sets.

2. The Association of American Universities includes 60 U.S. and 2 Canadian universities. In the U.S., AAU universities make up only $16 \%$ of all Ph.D. granting institutions, but more than $50 \%$ of all Ph.D.s graduate from one of these institutions each year. 3. According to the National Science Foundation, the unemployment rate for political scientists was $1.1 \%$, while the labor force participation rate was $91.5 \%$. However, $5.5 \%$ of political scientists were involuntarily out of the field. For social scientists more generally, unemployment was $0.9 \%$, labor force participation was $91.6 \%$, and
}

$3.9 \%$ were involuntarily out of the field. The proportion of doctorates involuntarily out of the field includes those individuals who are working part-time exclusively because no full-time work is available and those working in an area not related to their doctoral degree at least partially because suitable work in their field is unavailable (see Wilkinson 1997).

4. Bowen and Schuster (1986) named five factors that contributed to the increase in the number of part-time faculty members at

American colleges and universities: 1) a general decline in the prosperity of higher education; 2) efforts to achieve flexible staffing to accommodate shifting enrollments; 3 ) abundant supply of Ph.D.s; 4) growth of community colleges, which employ a large number of part timers; and 5) the expansion of life-long learning programs.

5. This figure might not be accurate. Schuster reported a $48 \%$ increase in parttime faculty and a $2.6 \%$ increase for full-time faculty between 1987 and 1992. However, the NEA (1996) reported an increase of $25 \%$ in full-time faculty between 1975 and 1993 .

6 . Women now represent more than onehalf of all students enrolled in graduate pro- grams. In 1995 , women received $46 \%$ of the doctoral degrees earned by U.S. citizens. Asian and Hispanic/Latina women are the two most rapidly growing groups in graduate education (Syverson 1997). The numbers of women in graduate programs has grown steadily at a, rate of 2 to $3 \%$ annually over the last 20 years (Syverson 1996).

7. This was the case between 1993 and 1995 as well, when members of minority groups either increased in their percentages among full-time faculty or retained a constant share of those positions. According to the NCES (1998), Asians and Pacific Islanders have made the greatest gains (increasing $9.0 \%$ ).

8. Racial differences are not as pronounced in this area, but the NEA reported in 1995 that Asians are less likely to teach part time than are members of any other racial or ethnic group.

9. Information about the APSA survey, CPST, and the National Science Foundation project are available at http://nextwave. sciencemag.org/survey. Additional information about APSA's survey and results are available in Mann (1998).

\section{References}

Association of American Universities. 1998 Graduate Education Report. Washington, DC: Association of American Universities. Barkume, Megan. 1996-97. "The Job-Market for Ph.D.s: Two Views." Occupational Outlook Quarterly 40(Winter): 2-15.

Benjamin, Ernst. 1998. "On the Excessive Reliance on Part-Time Faculty Appoint- ments." Academe 84(January-February): 26-27.

Bowen, Howard R., and Jack H. Schuester. 1986. American Professors: A National Re- 
source Imperiled. New York: Oxford University Press.

Conference on the Growing Use of Part-Time and Adjunct Faculty. 1998. "Statement." Academe 84(January-February): 54-60.

Foster, David, and Edith Foster. 1998. "It's a Buyer's Market: 'Disposable Professors,' Grade Inflation, and Other Problems.' Academe 84(January-February): 28-35.

Hartle, Terry W., and Fred J. Galloway. 1996. "Too Many Ph.D.s? Too Many MDs?" Change 28(September-October): 26-33.

Lapidus, Jules B. 1997. "Why Pursuing a Ph.D. Is a Risky Business." The Chronicle of Higher Education, November 14, A60.

Magner, Denise K. 1996a. "New Generation of Professors is Changing the Face of Academe." The Chronicle of Higher Education, February 2, A17.

—. 1996b. "Science Ph.D. Students Told to Prepare for Non-Academic Careers." The Chronicle of Higher Education, June 28, A18.

— 1997. "Job Market for Ph.D.s Shows First Signs of Improvement." The Chronicle of Higher Education, January 31, A8.

Mann, Sheilah. 1998. "Finding Jobs in Political Science: 1996 Placement Candidates Report on Their Employment Search and Outcomes." PS: Political Science and Politics 31(September): 591-608.

National Center for Education Statistics.
1996. Fall Staff in Postsecondary Institutions, 1993. NCES 96275. Washington, DC: Office of Educational Research and Improvement, Department of Education.

-. 1998. Fall Staff in Postsecondary Institutions, 1995. NCES 98228. Washington, DC: Office of Educational Research and Improvement, Department of Education.

National Education Association. 1995. "PartTime Faculty Members." Update 1(July).

—. 1996. "Full-Time Non-Tenure-Track Faculty." Update 2(September).

—. 1997. "Full-Time Non-Tenure-Track Faculty: Gender Differences." Update 3(November).

National Research Council. 1996. Doctorate Recipients from United States Universities. Washington, DC: Doctorate Records Project, National Research Council.

Pfannestiel, Todd. 1998. "It's Not Just a Job, It's an Indenture: Graduate Students and the Academic Job Market." Academe 84(January-February): 44-47.

Reichard, Gary W. 1998. "Part-Time Faculty in Research Universities: Problems and Prospects." Academe 84(January-February): $40-43$.

Rhoades, Gary, and Rachel Hendrickson. 1997. "Re(con)figuring the Professional Workforce." The NEA 1997 Almanac of Higher Education. Washington, DC: National Education Association.
Roemer, Robert E., and James E. Schnitz. 1982. "Academic Employment as Day Labor: The Dual Labor Market in Higher Education." The Journal of Higher Education 53(September-October): 514-31.

Shuster, Jack. 1998. "Reconfiguring the Professoriate: An Overview." Academe 84(January-February): 48-53.

Syverson, Peter D. 1996. "Assessing Demand for Graduate and Professional Programs." New Directions for Institutional Research 92(Winter): 17-29.

—. 1997. "The New Majority: CGS/GRE Survey Results Trace Growth of Women in Graduate Education" < http://www. cgsnet.org/vcr/cctr706.htm $>$. Virtual Center for Research on Graduate Education. Washington, DC: Council of Graduate Schools. Accessed: February 9, 2000.

Wilkinson, R. Keith. 1997. Doctoral Scientists and Engineers in the United States, 1995. NSF 97-319. Arlington, VA: Division of Science Resources, National Science Foundation.

Wilson, Robin. 1996. "Scholars off the 'Tenure Track Wonder if They'll Ever Get On." The Chronicle of Higher Education, June 14, A12.

—. 1997. "Career Success for Some Ph.D.s Comes by Leaving Academe Behind." The Chronicle of Higher Education, October 31 , A12. 